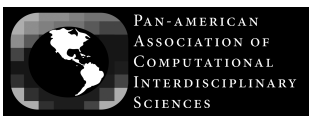

Journal of Computational Interdisciplinary Sciences (2008) 1(1): 57-70

(C) 2008 Pan-American Association of Computational Interdisciplinary Sciences

ISSN 1983-8409

http://epacis.org

\title{
Use of ordinary Kriging algorithm and wavelet analysis to understanding the turbidity behavior in an Amazon floodplain
}

\author{
Enner H. Alcântara
}

Manuscript received on July 28, 2008 / accepted on October 8, 2008

\begin{abstract}
The objective of this paper is to study the turbidity behavior in an Amazon Floodplain Lake. Observations of turbidity provide quantitative information about water quality conditions. However, the number of available in situ measurements of water quality characteristics is usually limited, especially temporal series variables and synoptic coverage of extensive water body. In order to contribute to the study of turbidity we present two approaches: (i) the first is based on wavelet analysis of a turbidity time series measured by an automatic monitoring system; (ii) the second is based on spatially distributed turbidity samples analized by Ordinary Kriging algorithm. The main results are: the space/time turbidity variability is related to Amazon river flood pulse in the floodplain; during the rising and receding water stages, the water exchange between Amazon river and floodplain is the major driven force in turbidity variability; during the high water level, the lake bathymetry controls turbidity variability; and during the low water level, the wind intensity and lake morphometry are the main causes of turbidity variability. The joint use of temporal and spatial data showed a great potential for understanding the turbidity behavior in a complex aquatic system, like the Amazon floodplain.
\end{abstract}

Keywords: Turbidity, Amazon Floodplain, Geostatistics, Spatial Modeling, Limnology. 


\section{INTRODUCTION}

Floodplains are dynamic and complex wetland systems, which periodically oscillate between terrestrial and aquatic phases (Junk 1997). Characterizing spatial heterogeneity and temporal change of water quality across floodplain systems is difficult using conventional sampling methodologies (George 1997; Dekker et al. 2002; Tyler et al. 2006). Also the study of water quality in these environments has been based mostly on datasets obtained at different sites or along track lines occupied during cruises (Jerosch et al. 2006; Alcântara et al., in press). Moreover, the number of in situ measurements of water quality is limited, especially in the form of time series and of spatial maps of variables (Zhang et al. 2003). With the availability of time series and the sampling of variables at different places wavelet analysis (Meyer et al. 1993; Kumar and Fouroula-Georgiou 1997) can be used to study the time localized frequency content of the signal and Geostatistics (Bellehumeur et al. 2000; Hedger et al. 2001) can be used to assess the spatial variability patterns of variables.

Geostatistics is focused on the spatial context and the spatial relationships present in the data. It provides tools for quantification and exploitation of spatial autocorrelation, and algorithms for data interpolation and uncertainty quantification (Isaaks and Srivastava 1989; Goovaerts 1997). The autocorrelation structure is used to estimate the variable values at points not sampled in the field (Bellehumeur et al. 2000). A central aspect of geostatistics is the use of spatial autocovariance structures, often represented by the (semi)variogram, or its cousin the autocovariogram, which differentiate different kinds of spatial variation (Burrough 2001).

Moreover, long-term high frequency time series of environmental variables are fundamental to identify and classify pulses or short duration variability in the data and to determine their impact in aquatic systems. The pulses are defined as any type of fast change suffered by the system variables (Stech et al. 2006). One of the better solutions to collect time series of aquatic systems is the installation of automatic stations with the capacity of autonomous monitoring of limnological and meteorological variables (Glasgow et al. 2004; Stech et al. 2006). With the installation of an associated telemetric link the constant surveillance provided by these systems can be fundamental to rapidly detect changes and trends in critical indicators (Glasgow et al. 2004). The high frequency, complexity and volume of the data generated by those telemetric monitoring systems render necessary the use of efficient analytical tools such as wavelet analysis (Meyers et al. 1993).

The wavelet analysis is becoming a common tool for analy- zing localized variations of power within an environmental time series (Meyer et al. 1993; Kumar and Fouroula-Georgiou 1997; Massei et al. 2006). By decomposing an environmental time series into time-frequency space enables the determination of both the dominant modes of variability and how those modes vary in time (Torrence and Compo 1998; Nakken 1999).

In this paper, we use the wavelet method on a long time series and Kriging spatial interpolation process to analyze the turbidity space/time behavior in the Curuai Floodplain located in the Brazilian Amazon region.

\section{STUDY SITE}

\subsection{Study site and background}

The Curuai floodplain (Fig. 1) covers an area varying from 1340 to $2000 \mathrm{~km}^{2}$ at the low and the high water levels, respectively. This floodplain, located $850 \mathrm{~km}$ from the Atlantic Ocean, near Óbidos city (Pará State, Brazil), is formed by 'white' water lakes characterized by high concentration of suspended sediments and 'black' water lakes with high concentration of dissolved organic matter and low concentration of sediments (Barbosa 2005). The floodplain also contains 'clear' water lakes fed by rainfall and rivers draining from the surrounding 'Terra Firme' (higher elevation terrain with no significant flooding events), (Junk 1997).

The lakes are connected to each other and also to the Amazon River. The Curuai floodplain is controlled by the Amazon River flood pulse, which creates four states in the floodplain-river system (Fig. 2). Water storage in floodplain starts between November and January and lasts until May-June. The drainage phase starts in July and lasts until November. The largest exported volume occurs from August to October. On an annual basis, the floodplain represents a source of water to the Amazon River (Bonnet et al. 2008). The residence time of the riverine water within the floodplain is 5 months \pm 0.8 month, while the residence time of water from all sources is $3 \pm 0.2$ months (Bonnet et al. 2008). The lowest and highest absolute water levels recorded at the Curuaí gauging station during the 1982-2003 period were $3.03 \mathrm{~m}$ and $9.61 \mathrm{~m}$, respectively, giving a maximum variation of $6.58 \mathrm{~m}$ (Bourgoin et al. 2007).

The exchange of water between the floodplain and the Amazon River is shown in Figure 2. When the water is closer to maximum level in the floodplain the exchange of flow is very low and the surface water circulation is caused mainly by wind (Alcântara et al., in press). In the receding state the exchange of water between the river and the floodplain is reversed, i.e., the flux is from the floodplain to the river. The water level drops near the lowest water 


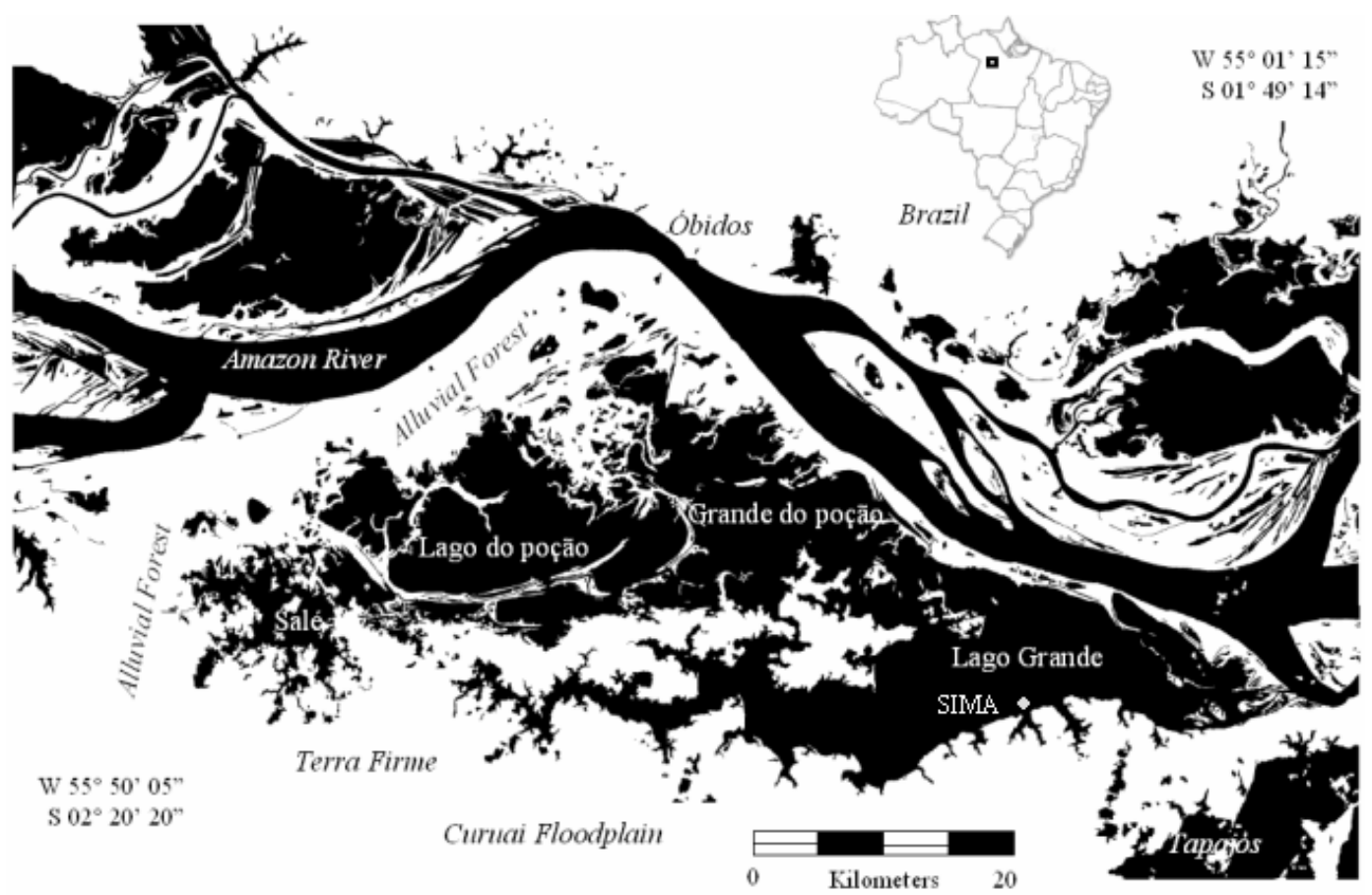

Figure 1 - Landsat-5 Thematic Mapper imagery showing the Curuai Floodplain (Pará State, Brazil) and the location of the automatic environmental data collection buoy system SIMA at Lago Grande.

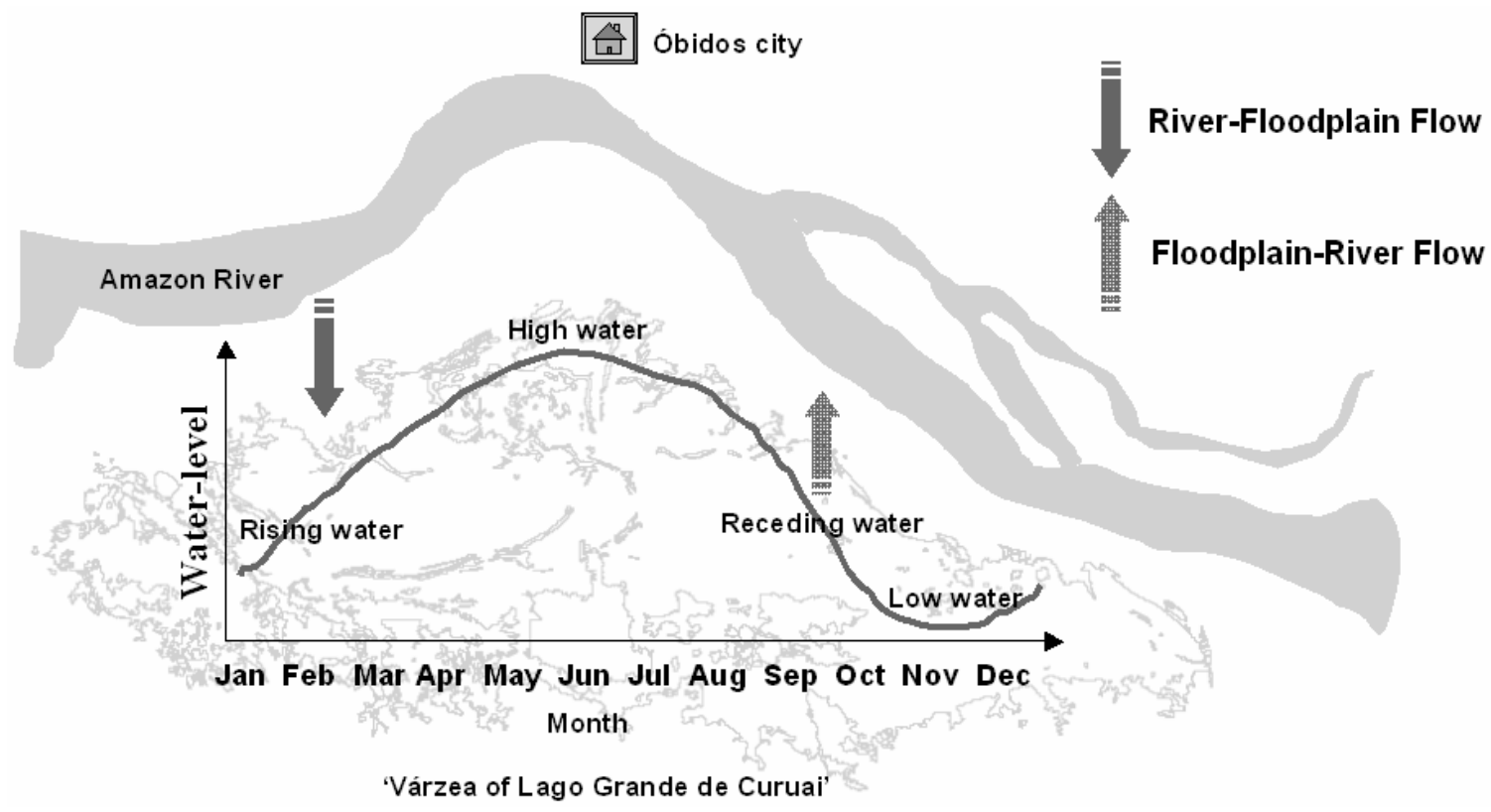

Figure 2 - Theoretical water level dynamics at Curuai Floodplain (from: Barbosa 2005). 
state, the exchange of water between the river and the floodplain is minimum.

\subsection{In situ data}

\subsubsection{Temporal domain}

The temporal variability of turbidity in Curuai floodplain was studied using the data collected by an anchored buoy system named Environmental Monitoring System - SIMA. SIMA system was developed by INPE and is composed an anchored buoy, in which meteorological and water quality sensors are installed supported by data storage systems, battery and the transmission antenna (Fig. 3a). The data are collected in preprogrammed time intervals ( 1 hour) and are transmitted by satellite in quasi-real time for any user in a range of $2500 \mathrm{~km}$ from the acquisition point. In this work we analyzed the time series of turbidity measurements from November 20, 2004 to April 26, 2005 (Fig. 3b).

During the high water period, the depth in the SIMA location is approximately $5.5 \mathrm{~m}$, considering the water level reference of $936 \mathrm{~cm}$ (Barbosa 2005) and $1.38 \mathrm{~m}$ during the low water stage with the water level reference of $524 \mathrm{~cm}$.

\subsubsection{Spatial domain}

Turbidity measurements were carried out from 2003 to 2004 at several stations at specific Curuai floodplain lake water level (Table 1) using a HORIBA U-10 multi-sensor probe. This equipment provides turbidity measurements in NTU (Nephelometric Turbidity Unit) with a resolution of 1 NTU and sensitivity from 0 up to 800 NTU. The HORIBA calibration was performed for each day of sampling. Sampling locations were defined based on Landsat5 TM images acquired during similar floodplain state (Barbosa 2005). The period of sampling by HORIBA and SIMA is different because the SIMA was installed at the end of 2004. According to Alcântara (2006) the turbidity in Curuai floodplain is controlled by flood pulse. For this reason the difference between HORIBA and SIMA samples does not intervene in the analysis.

\section{METHODOLOGICAL APPROACH}

\subsection{Wavelet analysis: the temporal domain}

To analyze the turbidity collected by SIMA we used the Morlet wavelet. The Morlet wavelet is the most common wavelet transform, which consist on a Gaussian-windowed complex sinusoid that is defined as following in the time and frequency domains:

$$
\psi_{0}(\eta)=\pi^{-\frac{1}{4}} e^{i \omega_{0} \eta} e^{-\frac{\eta^{2}}{2}}
$$

where $\omega_{0}$ is the non-dimensional frequency, here taken to be 6 to satisfy the admissibility condition (Farge 1992); $\eta$ is a nondimensional time parameter; $\psi_{0}(\eta)$ is the wavelet function.

Wavelet spectral power at different scale $(\omega)$ and time location $(\tau)$ can be calculated by

$$
P_{w}(\omega, \tau)=\mid W\left(\omega, \tau,\left.x(t)\right|^{2}\right.
$$

where $W$ is the wavelet transform described bellow.

The discrete wavelet method was used to simplify convolution calculation procedures with the scaled and normalized wavelet (Torrence and Compo 1998). The wavelet transform $W$ for a given time series $x$ is calculated by:

$$
W_{n}^{x}(\omega)=\sqrt{\frac{\delta t}{\omega}} \sum_{k^{\prime}=1}^{N} x_{n} \psi \times\left[(k-n) \frac{\delta t}{\omega}\right]
$$

where $\delta t$ is the uniform time step; $k^{\prime}$ is an integer from 1 to $N$ (number of data points); $x_{n}$ is the time series data. The scaleaveraged spectral-power-based wavelet analysis reflects the average variance for different time scales (frequency or period). The calculation procedures of discrete wavelet analysis were coded in Matlab 6.5 (The MathWorks, Inc., Natick, MA).

The high frequency turbidity time series have make it possible the study of bottom resuspension episodes that cause turbidity increases. Particularly in shallow lakes, some authors show the effects of wind as inducer sediment resuspension (Booth et al. 2000). These wind-induced physical processes are important for sediment transport and can be the dominant (Lou et al. 2000). We applied a method for predict the wind-induced bottom resuspension in the SIMA location during the low water stage.

\subsection{Predicting bottom resuspension events from wind-induced waves}

The minimum wind velocity (critical windspeed, $U_{c}$ ) needed to generate wave action reaching the bottom sediment was calculated according to Booth et al. (2000):

$$
U_{c}=\left\{1.2 \times\left[4127 \times\left(\frac{T_{c}^{3}}{F}\right)\right]^{0.813}\right\}
$$

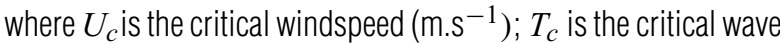
period; $F$ is the effective fetch $(m)$. The effective fetch was calculated according to Carper and Bachmann (1984).

The basic assumption of this simple model is that the effect of wave is felt up to a depth of approximately $\frac{L}{2}$, where $L$ is the 


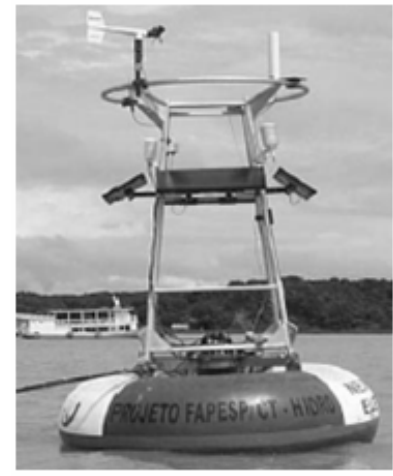

(a)

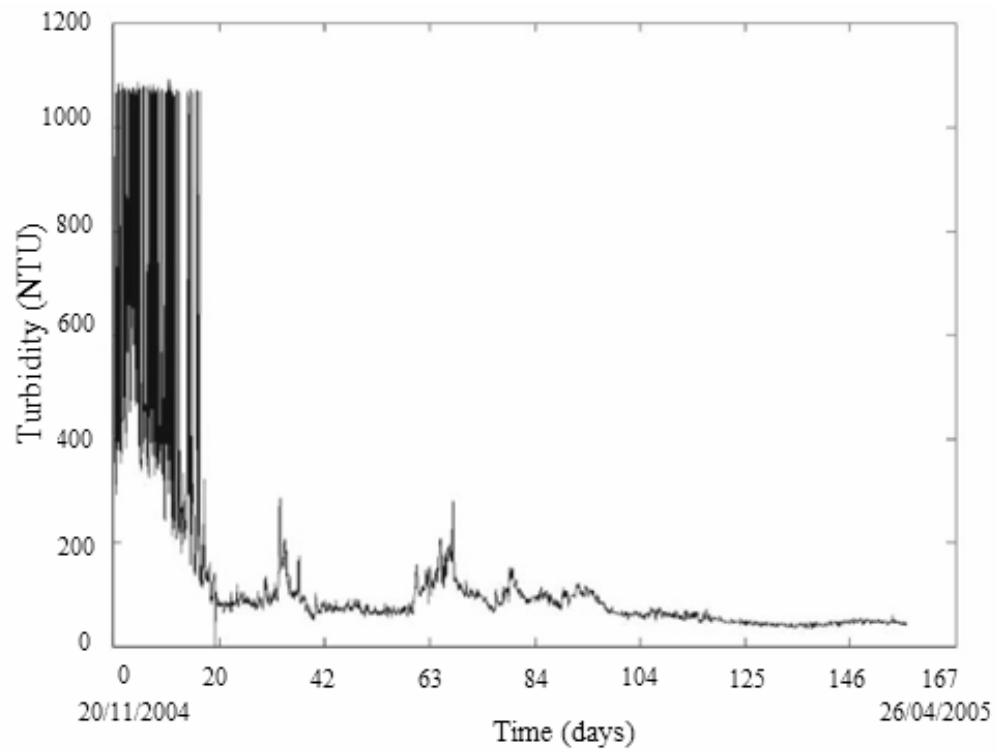

(b)

Figure 3 - (a) Photo of SIMA installed at Lago Grande in Curuai floodplain (See Figure 1 for location); (b) Temporal series of turbidity (NTU) collected by SIMA.

Table 1 - Descriptive statistics of in situ turbidity (NTU) data during the flood pulse.

\begin{tabular}{|l|c|c|c|c|c|c|}
\hline Water level & Period of sampling & $\begin{array}{c}\text { Number } \\
\text { of samples }\end{array}$ & $\begin{array}{c}\text { Maximum } \\
\text { value }\end{array}$ & Average & $\begin{array}{c}\text { Minimum } \\
\text { value }\end{array}$ & $\begin{array}{c}\text { Standard } \\
\text { deviation }\end{array}$ \\
\hline Receding water & $2003 / 9 / 23-2003 / 10 / 09$ & 208 & 375 & 163.06 & 12 & 58.61 \\
\hline Low water & $2003 / 11 / 19-2003 / 12 / 01$ & 202 & 1645 & 777.10 & 39 & 306.14 \\
\hline Rising water & $2004 / 02 / 01-2004 / 02 / 14$ & 221 & 569 & 232.29 & 101 & 84.61 \\
\hline High water & $2004 / 05 / 31-2004 / 06 / 21$ & 256 & 81 & 30.73 & 6 & 11.12 \\
\hline
\end{tabular}

Source: Barbosa (2005).

wavelength of the surface waves. So, if the water depth (d) is less than $\frac{L}{2}$ there is a wave energy transfer to the bottom sediments that can result in sediment resuspension.

The critical wave period $\left(T_{c}\right)$ is given by (CERC, 1984):

$$
T_{c}=\left(\frac{4 \times \pi \times d}{g}\right)^{\frac{1}{2}}
$$

\subsection{Ordinary Kriging: the spatial domain}

We used the Ordinary Kriging algorithm to interpolate in situ turbidity measurements and to produce the in situ turbidity map. The calculation of the Kriging weights is based upon the estimation of a semivariogram model, described as:

$$
\gamma(h)=\frac{1}{2} \operatorname{Var}[z(s+h)-z(s)]
$$

where: $\gamma(h)$ is an estimated value of the semivariance for lag $h$. The estimation of a semivariogram model relies on the important assumptions: the quantify $\gamma(h)$ exists and is finite for all choices of $h$ and $s$, and that it does not depend on $s$. The Ordinary Kriging estimator is:

$$
Z(x, y)=\sum_{i=1}^{n} w_{i} z_{i}
$$

where $n$ is the number of considered measures, $z_{i}$ are the corresponding attribute values, and wi are the weights (Isaaks and Srivastava 1989).

The semivariogram was fitted with several theoretical models (spherical, exponential, Gaussian, linear and power) using the weighted least square method. The theoretical model that gives minimum standard error was chosen for further analysis. 


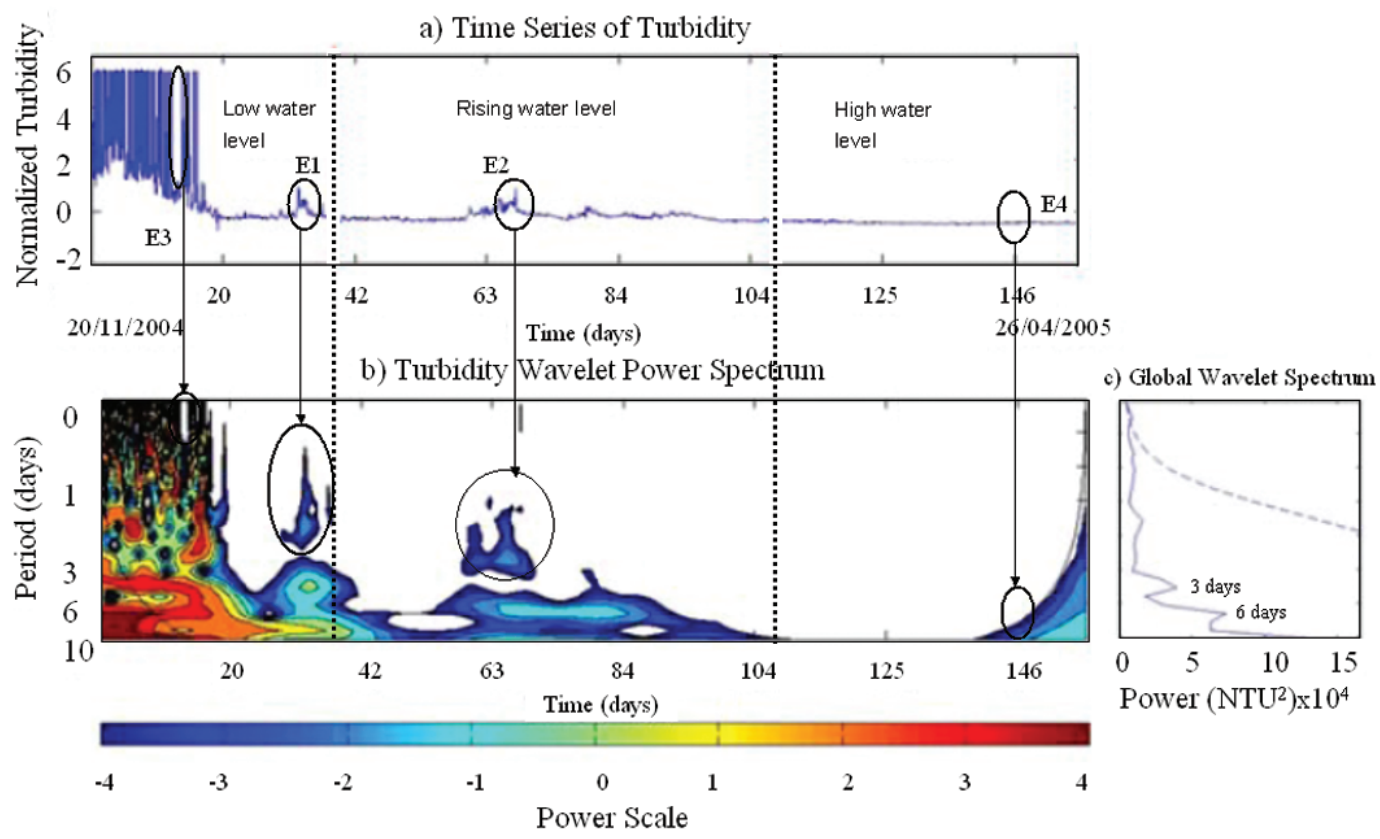

Figure 4 - Wavelet analysis of turbidity collected by SIMA from November 20, 2004 to April 20, 2005: (a) Temporal series of turbidity; (b) Turbidity wavelet power spectrum; (c) Global wavelet spectrum. The dashed lines delineate the water level stages.

Theoretical semivariogram models present three main coefficients that scales the fit to experimental semivariograms, namely range, sill and nugget effect: (i) range is a measurement of the curve's horizontal scale and corresponds to the maximum distance of spatial dependence; (ii) nugget effect is the y-intercept height and corresponds to a residual variation at the shortest sampling interval, random and not spatially correlated; (iii) sill is the remaining height of the curve above its y-intercept (nugget), and corresponds to the variance due to spatial structure (Isaaks and Srivastava 1989).

Semivariogram models often have different ranges and/or sills in different directions. For the case where only the range changes with direction, the anisotropy is known as geometric anisotropy, while in the case of only the sill changes with direction, the anisotropy is known as zonal anisotropy. The modeling of anisotropy usually starts by determining the anisotropy axes by experimentally determining the directions corresponding to the minimum and maximum range or sill (Isaaks and Srivastava 1989).

\section{RESULTS AND DISCUSSION}

\subsection{Wavelet analysis: the temporal domain}

The temporal series of turbidity collected by SIMA account with 3764 hourly samples (standard deviation of \pm 176.5 NTU) and a minimum, mean and maximum of 1.6, 126.9 and 1091 NTU, respectively (see Fig. 3b). To make easier the analysis the time series was subtracts from average and divided by standard deviation (Fig. 4a) in accordance to (Torrence and Compo 1998). In general the temporal series of turbidity shows a response to flood pulse in Curuai floodplain. A high value of turbidity, standard deviation and variance occurred when the water level is low (Fig. 4a).

The high mean values and standard deviation of turbidity during the low water level are caused mostly by wind. The wind stress induces an energetic wave-affected layer in which both large-scale orbital movements and the dissipated turbulent energy are important. The proximity of the surface and bottom boundaries in shallow lakes often generates a completely mixed water column during the resuspension events (Cózar et al. 2005). During the observational period winds acquired by SIMA at Lago Grande varied from 0.2 to $11 \mathrm{~m} . \mathrm{s}^{-1}$ with a preferential direction from southeast to northwest (Fig. 5).

It was observed two events (Fig. 4b) in the wavelet power spectrum that occur with quasi-same power: the first occurred during the low water level, approximately in the $41^{\circ}$ day after the beginning of the temporal measurements (December 31, 2004) while the second is closer to $63^{\circ}$ day (January 23, 2005). The first event (E1) refers to the exchange water from floodplain to Amazon River. The second event (E2) takes place when the water 


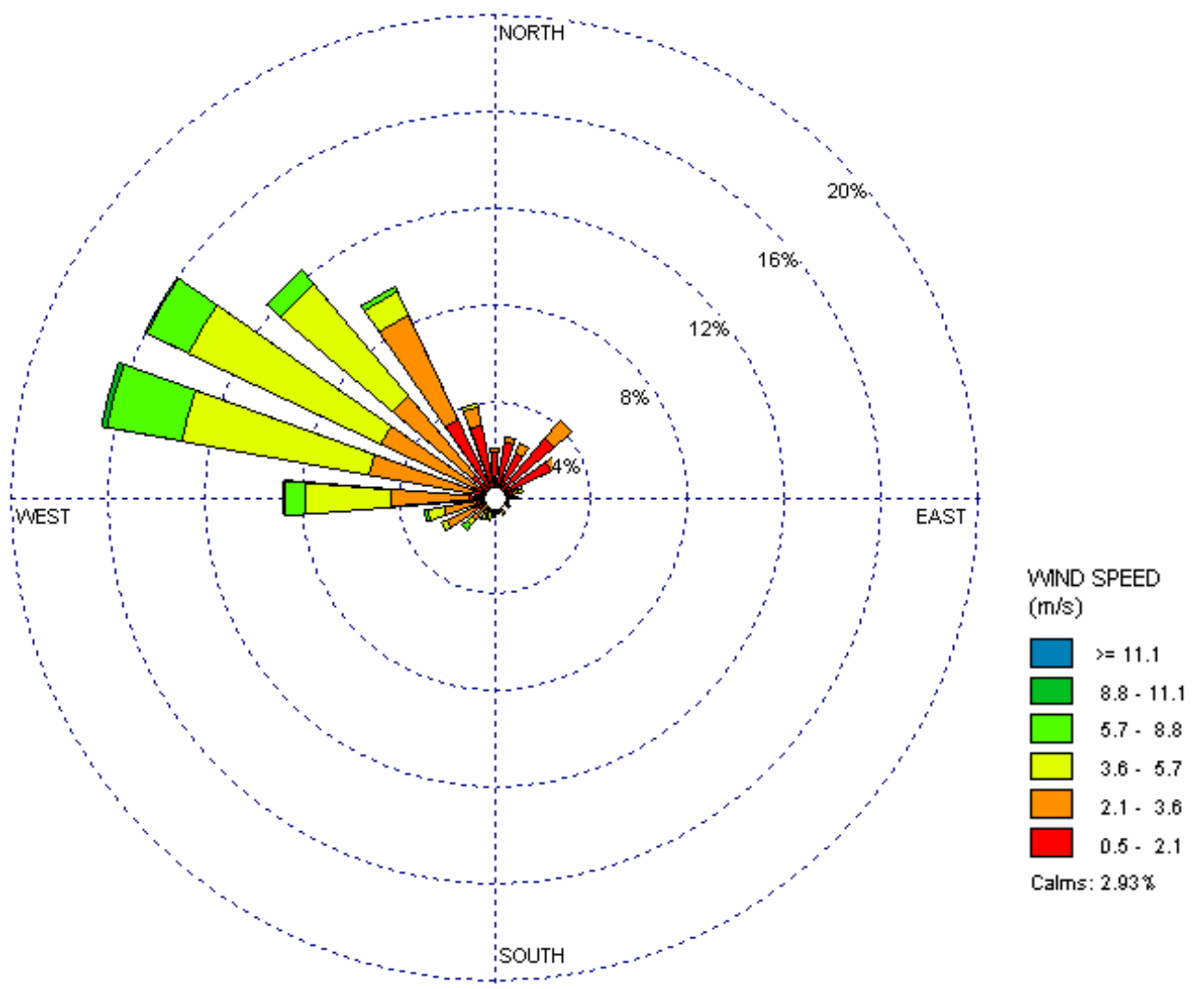

Figure 5 - Wind rose diagram of data collected by SIMA from November 20, 2004 to April 03, 2005.

level begins raise in response to the water from Amazon River to floodplain.

More two events of the wavelet power spectrum are highlight: the event E3 occurred during the low water level, approximately in the $17^{\circ}$ day after the beginning of the time series (December 4 , 2004), and show an abrupt fall in the turbidity; and the event E4 (April 13, 2005) when the water is near the maximum level.

The events E1, E2 and E3 occur probably due to the high wind intensity and the shallow water condition. In accordance to Carper and Bachmann (1984) the surface waves produced when wind blows across surface water cause the bottom resuspension and temporary increase the turbidity.

The first event (E1) has a minimum, mean and maximum wind velocity of $1.98,4.5$ and $5.75 \mathrm{~m}_{\mathrm{s}} \mathrm{s}^{-1}$, with a preferential wind direction from northwest to southeast, during 24-h (Fig. 6a). The second has a minimum, mean and maximum wind velocity of $0.34,2.37$ and $5.95 \mathrm{~m}^{-\mathrm{s}^{-1}}$, with a preferential wind direction from northeast to southwest, during 24-h (Fig. 6b). The third event (E3) has a minimum, mean and maximum wind velocity of 2.75, 5.47 and 9.02 m.s $\mathrm{s}^{-1}$ and preferential wind direction from northwest to southeast (Fig. 6c). And the fourth event (E4) with a wind direction from northwest to southeast has a minimum, mean and maximum wind velocity of $0.3,4.25$ and $7 \mathrm{~m}^{-1} \mathrm{~s}^{-1}$ respectively (Fig. 6d).

To verify that this highlights events in the Figure 4 is caused by wind-induced bottom resuspension we calculate the cri-

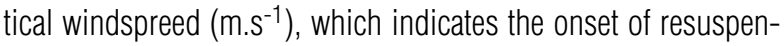

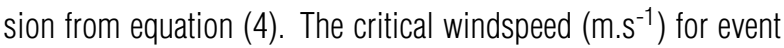
E1 (December 31, 2004) is 0.44 and $1.14\left({\mathrm{~m} . \mathrm{s}^{-1}}^{-1}\right.$ for January 23, 2005 (E2) (Table 2). For events E3 and E4, the critical windspeed are 1.04 and $5.02\left(\mathrm{~m}^{-1} \mathrm{~s}^{-1}\right)$. Windspeeds above these values makes suitable the bottom resuspension in the SIMA location. In both, E1 and E2 cases showing in the Figure $4 b$ is suitable for the wind-induced bottom resuspension.

Table 2 - Critical windspeed $\left(\mathrm{m} . \mathrm{s}^{-1}\right)$ to cause bottom sediment resuspension

\begin{tabular}{|c|c|c|c|}
\hline Depth $(\mathrm{m})$ & Events & Fetch $(\mathrm{m})$ & $\mathrm{Uc}\left(\mathrm{m}^{-1}{ }^{-1}\right)$ \\
\hline \multirow{2}{*}{1.38} & E1-December 31, 2004 & 33,000 & 0.44 \\
\cline { 2 - 4 } & E3-December 4, 2004 & 11,556 & 1.04 \\
\hline 2.32 & E2-January 23, 2005 & 10,300 & 1.14 \\
\hline 5.16 & E4-April 13, 2005 & 12,068 & 5.02 \\
\hline
\end{tabular}




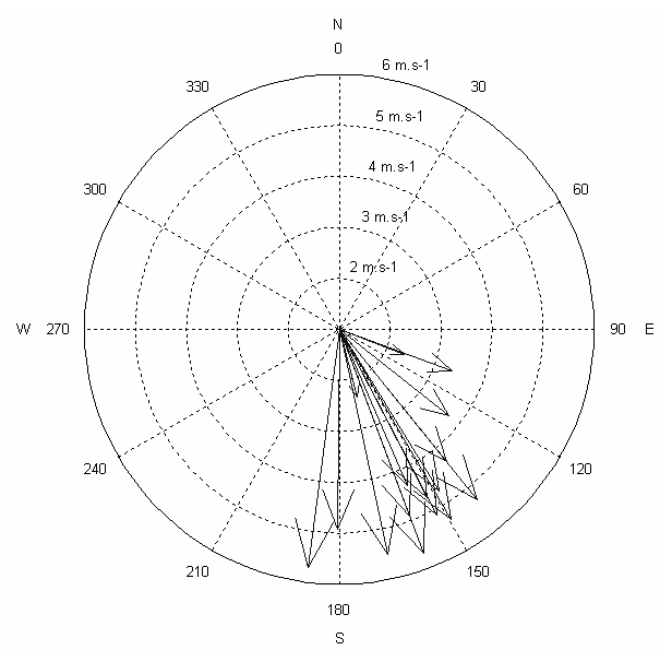

(a)

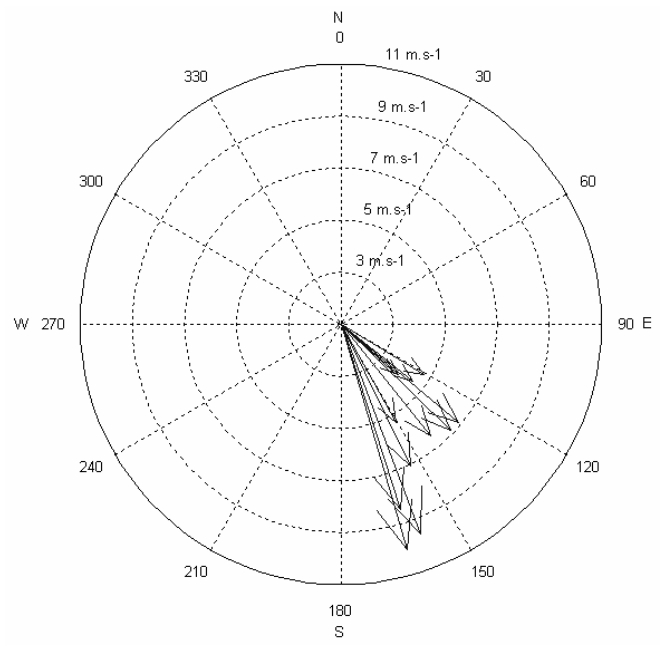

(c)

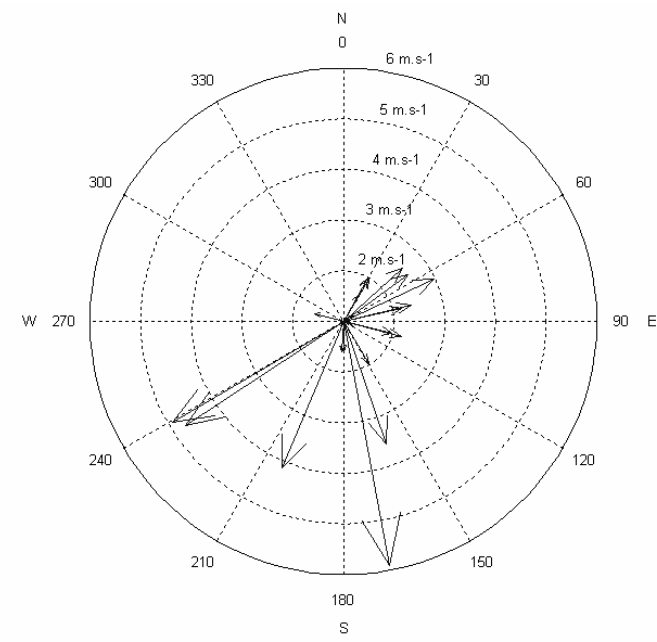

(b)

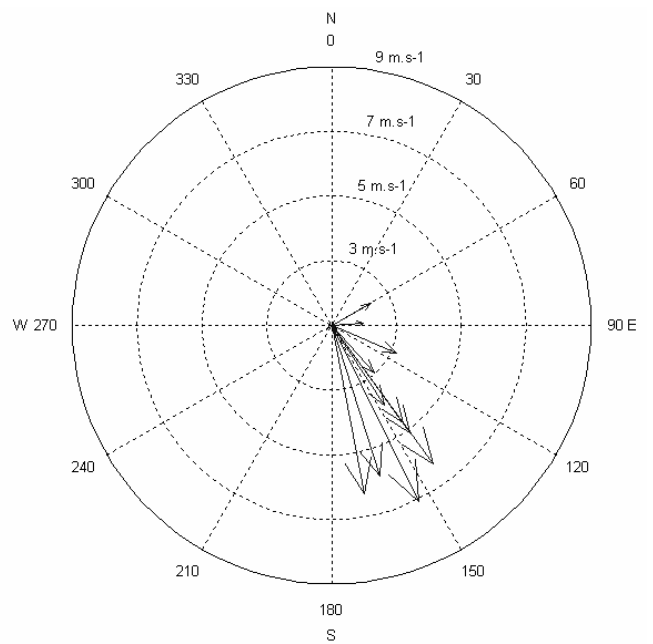

(d)

Figure 6 - Compass wind roses: (a) E1-December 31, 2004; (b) E2-January 23, 2005; (c) E3-December 4, 2004 and (d) E4-April 13, 2005.

The Figure 4 shows a low turbidity during the low water level, that characterize the event E3. For event E3 all wind speed is above the critical windspeed. As a result, the sediment resuspension can occur. Note that, the duration of the minimum

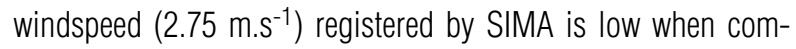
pared with the time series in this water stage. As a consequence occur the suspended solids decantation due to the end of the wind action in the surface water. In accordance to MoreiraTurcq (2004) the silt and clay dominate the suspended solids in Curuai floodplain (87-98\%), and at the end of wind action and the decrease of the current velocity would cause particle settling.
The highlighted region E4 shows a critical windspeed of $5.02 \mathrm{~m} . \mathrm{s}^{-1}$ with a maximum wind velocity of $7 \mathrm{~m} . \mathrm{s}^{-1}$ and accordance to equation (4) it is possible occur the bottom resuspension. However, the resuspension is moderate due to the high water level and is dependent of the wind velocity duration above critical windspeed.

These explain the fact of the global wavelet spectrum shows two significant periods of variance: 3 and 6 days (Fig. 4c). Because the high windspeed occurring of 3 in 3 days that makes suitable for the highest bottom resuspension in the low water stage, that dominates the temporal series of turbidity. To verify the turbidity distribution in all floodplain lakes we apply the 
Ordinary Kriging on turbidity collected in situ by a HORIBA U-10 multi-sensor.

\subsection{Kriging interpolation: spatial domain}

All in situ turbidity data was interpolated using the ordinary Kriging algorithm to assess the turbidity distribution and variability in response to flood pulse. According to Bonnet et al. (2008) the water storage within the floodplain started between December and February, and lasted until June. From this time until the end of the water year, water was exported from the floodplain into the river. From August to September occurred the maximum water export.

\subsubsection{Rising water level}

The parameters of the semivariogram model for the collected turbidity during the rising water level are presented in Table 3. We modeled the anisotropy for the angle of $94^{\circ}$ and were necessary three structures to perform the modeling. The mathematical representation is the following

$$
\begin{aligned}
& \gamma(h)= 619+114\left[\operatorname{Gau}\left(\sqrt{\left(\frac{h_{94^{\circ}}}{\varepsilon}\right)^{2}+\left(\frac{h_{216^{\circ}}}{16436}\right)^{2}}\right)\right] \\
&+ 7770\left[\operatorname{Gau}\left(\sqrt{\left(\frac{h_{94^{\circ}}}{17924}\right)^{2}+\left(\frac{h_{216^{\circ}}}{16436}\right)^{2}}\right)\right] \\
&+1480\left[\operatorname{Gau}\left(\sqrt{\left(\frac{h_{94^{\circ}}}{17924}\right)^{2}+\left(\frac{h_{216^{\circ}}}{\infty}\right)^{2}}\right)\right]
\end{aligned}
$$

where: $\gamma(h)$ is the semivariance at lag $h, h_{94}$ are the semivariance due to the angle of $94^{\circ} ; h_{216}$ is the semivariance due to the angle of $216^{\circ} ; \varepsilon$ is the range for the direction of $94^{\circ} ; \mathrm{Gau}$ is a Gaussian model.

The variogram was fit with a Gaussian model that indicates a smoothly varying pattern (Burrough and McDonnell 1998) in turbidity (Fig. 7).

According to Barbosa (2005), during the rising water level, the flow from Amazon River to the Curuai floodplain starts in a channel located at the eastern border of the lake, then migrating to small channels at the northwestern border. So, the yellow circle 1 show a region of high turbidity that was formed by the water from Amazon River entering through the channel located in eastern border; and the high turbidity on yellow circle 2 was formed by the entrance water from Amazon River through the small channels located on northwestern side (Fig. 7). The yellow circle 3 is the region of low turbidity. The low turbidity in this region of low variability in suspended solids is explained by the existence of a natural barrier as previously reported (Barbosa 2005).

\subsubsection{High water level}

The anisotropy modeling for the high water level was performed and the parameters used in the interpolation are presented in Table 4.

The angle of anisotropy was $100^{\circ}$ and was necessary three structures to perform the modeling. The mathematical representation is the following

$$
\begin{aligned}
\gamma(h)= & 4.98+20.45\left[\operatorname{Gau}\left(\sqrt{\left(\frac{h_{100^{\circ}}}{\varepsilon}\right)^{2}+\left(\frac{h_{233^{\circ}}}{14637}\right)^{2}}\right)\right] \\
& +119.64\left[\operatorname{Gau}\left(\sqrt{\left(\frac{h_{100^{\circ}}}{12003}\right)^{2}+\left(\frac{h_{233^{\circ}}}{14637}\right)^{2}}\right)\right] \\
& +8.2\left[\operatorname{Gau}\left(\sqrt{\left(\frac{h_{100^{\circ}}}{12003}\right)^{2}+\left(\frac{h_{230^{\circ}}}{\infty}\right)^{2}}\right)\right]
\end{aligned}
$$

where: $\gamma(h)$ is the semivariance at lag $h, h_{100}$ and $h_{233}$ are the semivariance due to the angle of $94^{\circ}$ and $233^{\circ}$ respectively; $\varepsilon$ is the range for the direction of $100^{\circ}$; Gau is a Gaussian model.

During the high water level the input of water from Amazon River is minimum and the turbidity tend to be spatially homogeneous. The areas of high turbidity are 1 and 2 and correspond to the small channels interconnected with Amazon River. The area 3 also corresponds to the interconnected channel, however the turbidity is low (Fig. 8). This occurs probably because this channel is the first to cease the water input to floodplain. The area 4 has a low turbidity due to the forest cover that favors a decrease in flow velocity and particle settling due to the lower hydrodynamics.

\subsubsection{Receding water level}

The anisotropy modeling for the high water level was performed and the used parameters can be accessed in Table 5 .

The angle of anisotropy was $94^{\circ}$ and was necessary three structures to perform the modeling. The mathematical representation is the following

$$
\begin{aligned}
\gamma(h)= & 401+229\left[\operatorname{Exp}\left(\sqrt{\left(\frac{h_{94}}{\varepsilon}\right)^{2}+\left(\frac{h_{216^{\circ}}}{12402}\right)^{2}}\right)\right] \\
& +3567\left[\operatorname{Exp}\left(\sqrt{\left(\frac{h_{940^{\circ}}}{16424}\right)^{2}+\left(\frac{h_{216^{\circ}}}{12402}\right)^{2}}\right)\right] \\
& +261\left[\operatorname{Exp}\left(\sqrt{\left(\frac{h_{940^{\circ}}}{16424}\right)^{2}+\left(\frac{h_{216^{\circ}}}{\infty}\right)^{2}}\right)\right]
\end{aligned}
$$


Table 3 - Semivariogram parameters to interpolate the turbidity in rising water level.

\begin{tabular}{|c|c|c|c|c|c|c|}
\hline $\begin{array}{c}\text { Anisotropy } \\
\text { direction }\end{array}$ & Structure & Nugget & Sill & $>$ range & $<$ range & Model \\
\hline \multirow{3}{*}{$94^{\circ}$} & $1^{\circ}$ & \multirow{3}{*}{619} & 114 & 16436 & $\varepsilon$ & \\
\cline { 2 - 4 } & $2^{\circ}$ & 7770 & 17924 & 16436 & \multirow{2}{*}{ Gaussian } \\
\cline { 2 - 4 } & $3^{\circ}$ & & 1480 & $\infty$ & 17924 & \\
\hline
\end{tabular}

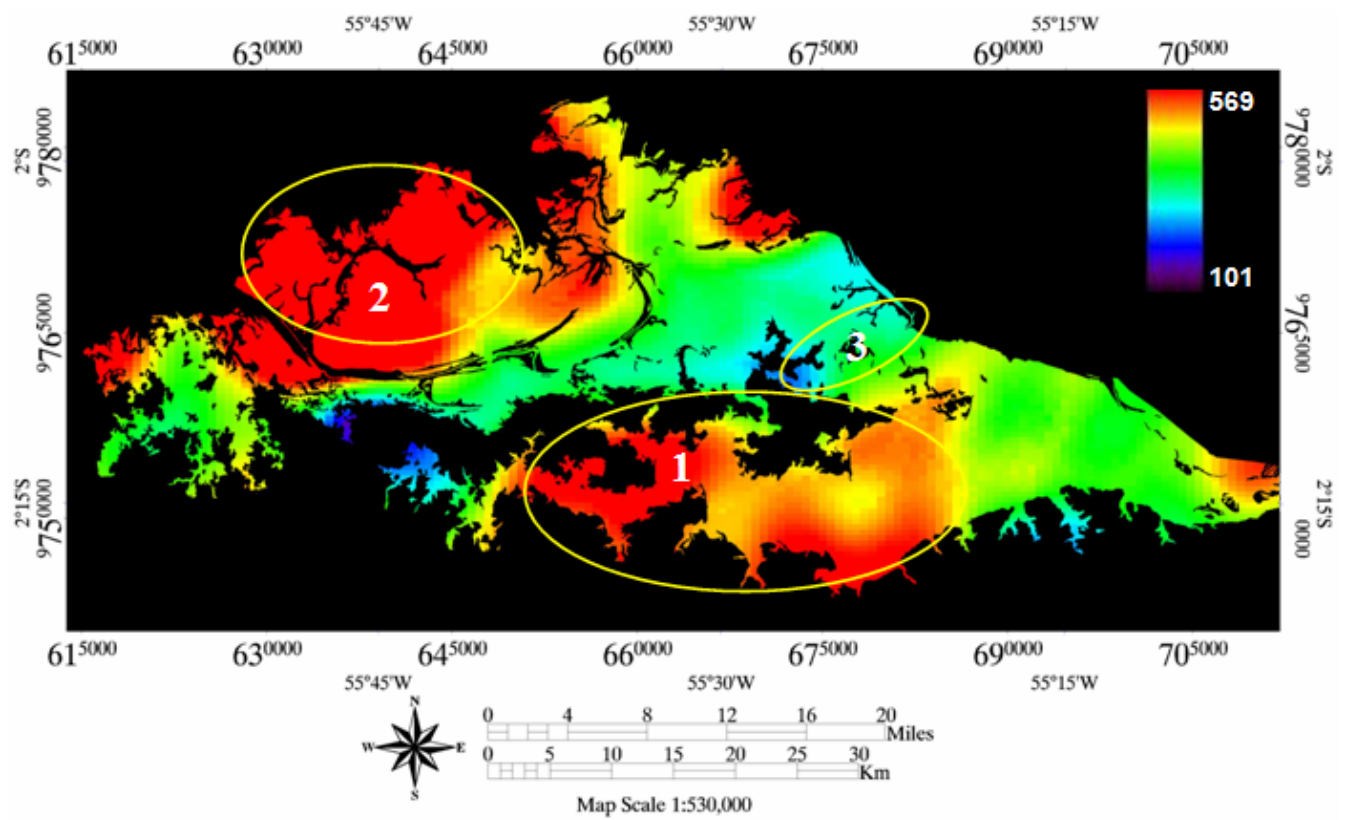

Figure 7 - Turbidity Distribution (NTU) in Curuai Floodplain interpolated using the ordinary Kriging during rising water level.

Table 4 - Semivariogram parameters to interpolate the turbidity in high water level.

\begin{tabular}{|c|c|c|c|c|c|c|}
\hline $\begin{array}{c}\text { Anisotropy } \\
\text { direction }\end{array}$ & Structure & Nugget & Sill & $>$ range & $<$ range & Model \\
\hline \multirow{3}{*}{$100^{\circ}$} & $1^{\circ}$ & \multirow{3}{*}{4.98} & 20.45 & 14637 & $\varepsilon$ & \multirow{2}{*}{ Gaussian } \\
\cline { 2 - 5 } & $2^{\circ}$ & 119.64 & 14637 & 12003 & \\
\cline { 2 - 2 } & $3^{\circ}$ & & 8.2 & $\infty$ & 12003 & \\
\hline
\end{tabular}

Table $\mathbf{5}$ - Semivariogram parameters to interpolate the turbidity in receding water level.

\begin{tabular}{|c|c|c|c|c|c|c|}
\hline $\begin{array}{c}\text { Anisotropy } \\
\text { direction }\end{array}$ & Structure & Nugget & Sill & $>$ range & $<$ range & Model \\
\hline \multirow{2}{*}{$94^{\circ}$} & $1^{\circ}$ & \multirow{3}{*}{401} & 229 & 12402 & $\varepsilon$ & \\
\cline { 2 - 5 } & $2^{\circ}$ & 3567 & 16424 & 12402 & \multirow{2}{*}{ Exponential } \\
\cline { 5 - 6 } & $3^{\circ}$ & & 261 & $\infty$ & 16242 & \\
\hline
\end{tabular}




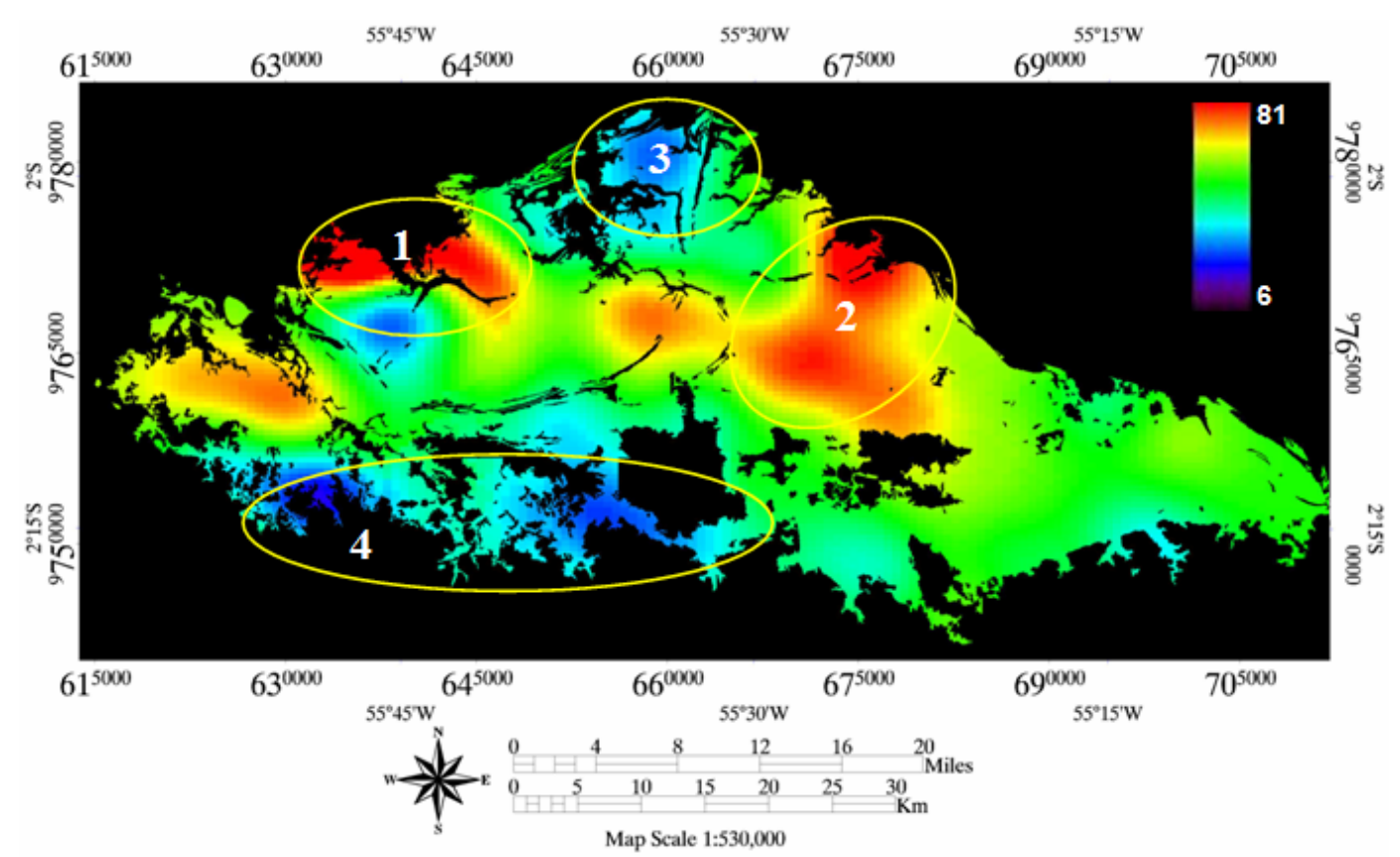

Figure 8 - Turbidity Distribution (NTU) in Curuai Floodplain interpolated using the ordinary Kriging during high water level.

where: $\gamma(h)$ is the semivariance at lag $h, h_{94}$ and $h_{216}$ are the semivariance due to the angle of $94^{\circ}$ and $216^{\circ}$ respectively; $\varepsilon$ is the range for the direction of $94^{\circ} ; \operatorname{Exp}$ is a Exponential model.

An empirical semivariogram fitted to an exponential function suggests a dataset with a spatial pattern characterized by gradual transition among several patterns interfering with each other (Burrough and McDonnell 1998). The Figure 9 shows the gradual transition of turbidity in the Curuai floodplain.

According to Barbosa (2005) during the receding water level the preferential direction of flow is from west to east. As a result, the regions under the yellow circles 1 and 2 show a high turbidity due to the friction of water within the small channels borders. The circle 3 represents the suspended solids which entering by east channel connected by Amazon River (Fig. 9). The receding water level stage causes a condition of turbulent flow, as a result, the turbidity tends to increase.

\subsubsection{Low water level}

To interpolate the turbidity in low water level we modeled the anisotropy. The used parameters to perform the interpolation using the Ordinary Kriging algorithm are presented in Table 6.

The angle of anisotropy was $94^{\circ}$ and the modeling was im- plemented with three structures as follows:

$$
\begin{aligned}
\gamma(h)= & 8420+7140\left[\operatorname{Gau}\left(\sqrt{\left(\frac{h_{94}}{\varepsilon}\right)^{2}+\left(\frac{h_{216^{\circ}}}{6140}\right)^{2}}\right)\right] \\
& +66885\left[\operatorname{Gau}\left(\sqrt{\left(\frac{h_{94^{\circ}}}{9379}\right)^{2}+\left(\frac{h_{216^{\circ}}}{6140}\right)^{2}}\right)\right] \\
& +10430\left[\operatorname{Gau}\left(\sqrt{\left(\frac{h_{94^{\circ}}}{9379}\right)^{2}+\left(\frac{h_{216^{\circ}}}{\infty}\right)^{2}}\right)\right]
\end{aligned}
$$

where: $\gamma(h)$ is the semivariance at lag $h, h_{94}$ and are the semivariance due to the angle of $94^{\circ}$ and 216 , respectively; $\varepsilon$ is the range for the direction of $94^{\circ}$; $G a u$ is a Gaussian model. During the low water stage the water exchange between Amazon River and Curuai floodplain is minimum and the turbidity variability is mainly driven by wind intensity. As previously discussed, the preferential direction is from southeast to northwest (Fig. 5). This preferential wind direction causes a water piling up and generates a dowelling near the margins of channels and an upwelling in a opposite direction. These regions can be seen in the yellow circles 1 and 2 (Fig. 10).

\section{CONCLUSIONS}

This study presents an analysis of the spatial-temporal dynamics of the turbidity in the Curuai floodplain. 


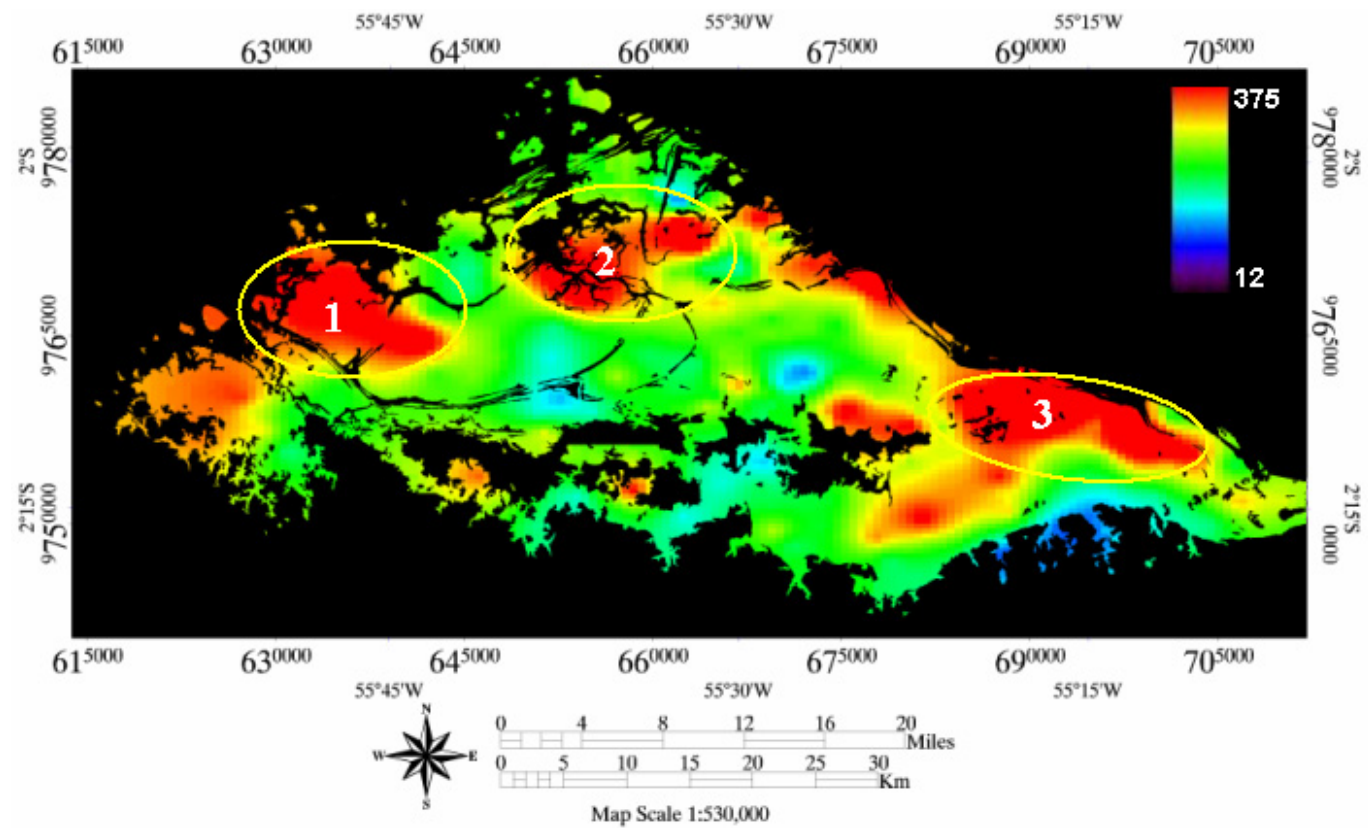

Figure 9 - Turbidity Distribution (NTU) in Curuai Floodplain interpolated using the ordinary Kriging during receding water level.

Table 6 - Semivariogram parameters to interpolate the turbidity in low water level.

\begin{tabular}{|c|c|c|c|c|c|c|}
\hline $\begin{array}{c}\text { Anisotropy } \\
\text { direction }\end{array}$ & Structure & Nugget & Sill & $>$ range & $<$ range & Model \\
\hline \multirow{3}{*}{$94^{\circ}$} & $1^{\circ}$ & \multirow{3}{*}{8420} & 63595 & 9379 & $\varepsilon$ & \\
\cline { 2 - 4 } & $2^{\circ}$ & 66885 & 9379 & 6140 & \multirow{2}{*}{ Gaussian } \\
\cline { 2 - 4 } & $3^{\circ}$ & & 10430 & $\infty$ & 9379 & \\
\hline
\end{tabular}

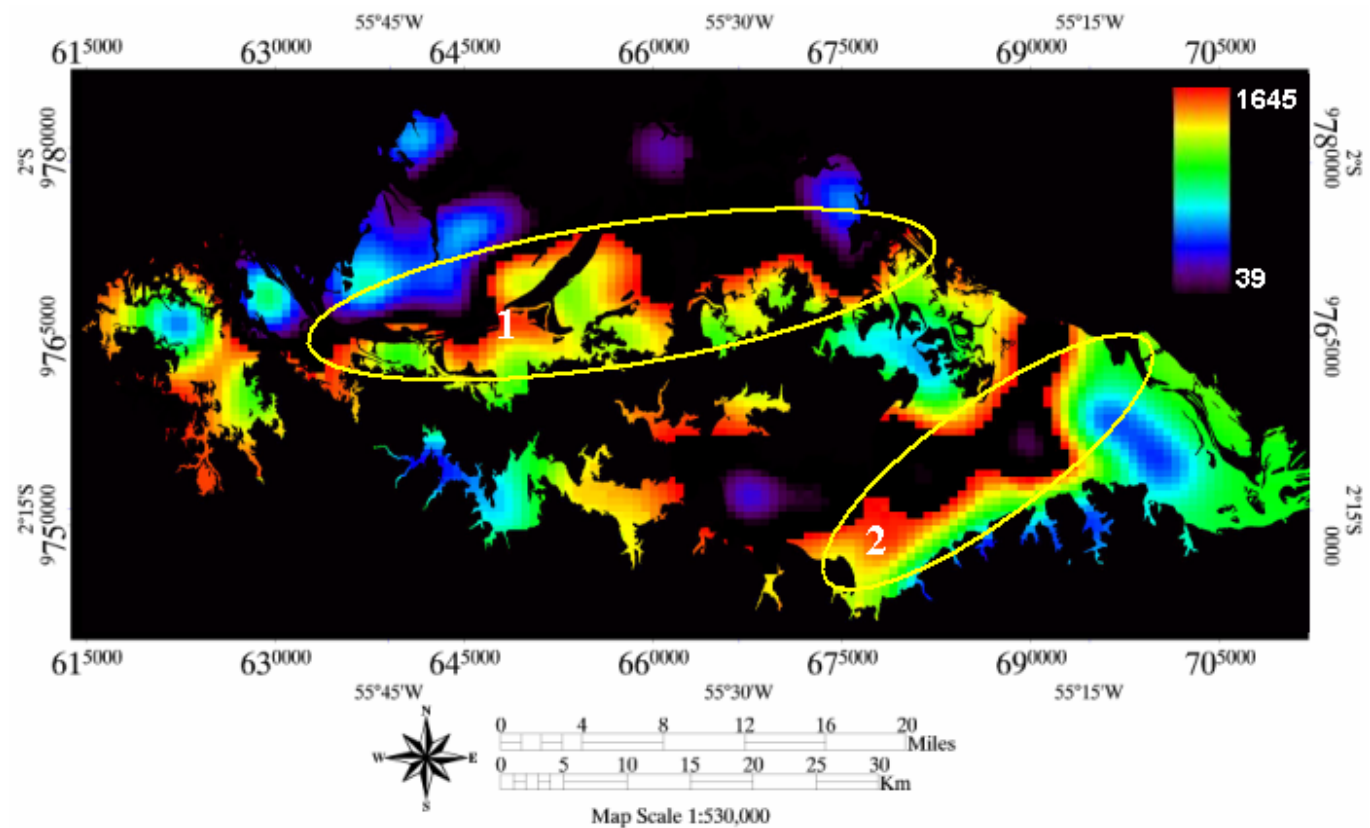

Figure 10 - Turbidity Distribution (NTU) in Curuai Floodplain interpolated using the ordinary Kriging during low water level. 
The temporal series of turbidity analyzed with wavelet transform shows the dependence of turbidity variability with flood pulse in the system Amazon River-Curuai floodplain.

The analyzes of turbidity samples spatially distributed with Ordinary Kriging algorithm showed the same dependence observed in the temporal series. The Ordinary Kriging maps also show the locations of high turbidity in floodplain in each water level stage. During the low water level is clear that the wind intensity is the mainly driven force to generate a high turbidity in Curuai floodplain.

The computational data integration of spatio-temporal information proposed here shows a great potential for the understanding of turbidity dynamics in complex aquatic systems.

\section{ACKNOWLEDGMENT}

The authors are grateful to the Brazilian funding agency FAPESP under grants 02/09911-1 and the Brazilian Council for Scientific and Technological Development (CNPq) to M.Sc fellowship to E.H. Alcântara. We also thank C. Torrence and G. Compo for provides the Wavelet software available at URL: http://atoc.colorado.edu/research/wavelets/.

\section{REFERENCES}

ALCÂNTARA EH. 2006. Análise da Turbidez na Planície de Inundação de Curuaí (PA, Brasil) Integrando Dados Telemétricos e Imagens MODIS/Terra. (MSc. Dissertation) - Instituto Nacional de Pesquisas Espaciais - (INPE), São José dos Campos, Brazil.

ALCÂNTARA EH, STECH JL, NOVO EMLM, SHIMABUKURO YE \& BARBOSA CCF. (in press). Turbidity in the Amazon floodplain assessed through a spatial regression model applied to fraction images derived from MODIS/Terra. IEEE Transactions on Geoscience and Remote Sensing.

BARBOSA CCF. 2005. Sensoriamento remoto da dinâmica de circulação da água do sistema planície de Curuai/Rio Amazonas. (Ph.D. Thesis) Instituto Nacional de Pesquisas Espaciais - (INPE), São José dos Campos, Brazil.

BELLEHUMEUR C, MARCOTTE D \& LEGENDRE P. 2000. Estimation of regionalized phenomena by geostatistical methods: lake acidity on the Canadian Shield. Environmental Geology, 39: 211-220.

BONNET MP, BARROUX G, MARTINEZ JM, SEYLER F, MOREIRATURCQ P, COCHONNEAU G, MELACK JM, BOAVENTURA G, MAURICEBOURGOIN L, LEÓN JG, ROUX E, CALMANT S, KOSUTH P, GUYOT JL \& SEYLER P. 2008. Floodplain hydrology in an Amazon floodplain lake (Lago Grande de Curuaí). Journal of Hydrology, 349: 18-30.
BOOTH JG, MILLER RL, McKEE BA \& LEATHERS RA. 2000. Windinduced bottom sediment resuspension in a microtidal coastal environment. Continental Shelf Research, 20: 785-806.

BOURGOIN LM, BONNET MP, MARTINEZ JM, KOSUTH P, COCHONNEAU G, MOREIRA-TURCQ ??, GUYOT JL, VAUCHEL P, FILIZOLA N \& SEYLER P. 2007. Temporal dynamics of water and sediment exchanges between the Curuai floodplain and the Amazon River, Brazil. Journal of Hydrology, 335: 140-156.

BURROUGH PA. \& McDONNELL RA. 1998. Principles of geographical information systems. New York: Oxford University Press.

BURROUGH PA. 2001. GIS and Geostatistics: Essential partners for spatial analysis. Environmental and Ecological Statistics, 8: 361-377.

CARPER GL \& BACHMANN RW. 1984. Wind resuspension of sediments in a prairie lake. Can. J. Fish. Aquat. Sci., 41: 1763-1767.

CÓZAR A, GÁLVEZ JA, HULL V, GARCÍA CM \& LOISELLE SA. 2005. Sediment resuspension by Wind in a shallow lake of Esteros Del Iberá (Argentina): a model based on turbidimetry. Ecological Modelling, 186: 63-76.

DAUBECHIES I. 1990. The wavelet transform, time-frequency location and signal analysis. IEEE Transactions on Information Theory, 36: 961-1005.

DEKKER AG, VOS RJ \& PETERS SWM. 2002. Analytical algorithms for lake water TSM estimation for retrospective analyses of TM and SPOT sensor data. International Journal of Remote Sensing, 23: 15-35.

FARGE M. 1992. Wavelet transforms and their applications to turbulence. Ann. Rev. Fluid Mech., 24: 395-457.

GAUCHEREL C. 2002. Use of wavelet transform for temporal characterisation of remote watersheds. Journal of Hydrology, 269: 101-121.

GEORGE DG. 1997. The airborne remote sensing of phytoplankton chIorophyll in the lakes and tarns of the English Lake District. International Journal of Remote Sensing, 18: 1961-1975.

GLASGOW HB, BURKHOLDER JM, REED RE, LEWITUS AJ \& KLEINMANN JE. 2004. Real-time remote monitoring of water quality: a review of current applications, and advancements in sensor, telemetry, and computing technologies. Journal of Experimental Marine Biology and Ecology, 300: 409-448.

GOOVAERTS P. 1997. Geostatistics for natural resources evaluation. New York: Oxford University Press.

HEDGER RD, ATKINSON PM \& MALTHUS TJ. 2001. Optimizing sampling strategies for estimating mean water quality in lakes using geostatistical techniques with remote sensing. Lakes \& Reservoirs: Research and Management, 6: 279-288.

ISAAKS EH \& SRIVASTAVA MR. 1989. An introduction to applied geostatistics. New York: Oxford University Press, $561 \mathrm{p}$. 
JEROSCH K, SCHLÜTER M \& PESCH R. 2006. Spatial analysis of marine categories information using indicator Kriging applied to georeferenced video mosaics of the deep-sea Håkon Mosby Mud Volcano. Ecological Informatics, 1: 391-406.

JUNK WJ. 1997. The Central Amazon Floodplain: ecology of a pulsing system. Berlin: Springer Verlag.

KUMAR P \& FOUROULA-GEORGIOU E. 1997. Wavelet analysis for geophysical application. Reviews of Geophysics, 35: 385-412.

MASSEI N, DUPONT JP, MAHLER BJ, LAIGNEL B, FOURNIER M, VALDES D \& OGIER S. 2006. Investigating transport properties and turbidity dynamics of a karst aquifer using correlation, spectral, and wavelet analyses. Journal of Hydrology, 329: 244-257.

MEYERS SD, KELLY BG \& O'BRIEN JJ. 1993. An introduction to wavelet analysis in Oceanography and Meteorology: with application to the dispersion of Yanai Waves. Mon. Wea. Rev., 121: 2858-2866.

MOREIRA-TURCQ PF, JOUANNEAU B, TURCQ B, SEYLER P, WEBER 0 \& GUYOT JL. 2004. Carbon sedimentation at Lago Grande de Curuaí, a floodplain lake in the low Amazon region: insight into sedimentation rates. Palaeogeography, Palaeoclimatology, Palaeoecology, 214: 27-70.

NAKKEN M. 1999. Wavelet analysis of rainfall-runoff variability isolating climatic from anthropogenic patterns. Environmental Modelling \& Software, 14: 283-295.
LOU J, SCHWAB DJ, BELETSKY D \& HAWLEY N. 2000. A model of sediment resuspension and transport dynamics in southern Lake Michigan. Journal of Geophysical Research, 105: 6591-6610.

STECH JL, LIMA IBT, NOVO EMLM, SILVA CM, ASSIREU AT, LORENZZETTI JA, CARVALHO JC, BARBOSA CCF \& ROSA RR. 2006. Telemetric Monitoring System for meteorological and limnological data acquisition. Verh. Internat. Verein. Limnol., 29: 1747-1750.

TYLER AN, SVAB E, PRESTON E, PRÉSING M \& KOVÁCS WA. 2006. Remote sensing of the water quality of shallow lakes: A mixture modelling approach to quantifying phytoplankton in water characterized by high-suspended sediment. International Journal of Remote Sensing, 27: 1521-1537.

TORRENCE C \& COMPO GP. 1998. A Practical Guide to Wavelet Analysis. Bull. Amer. Meteor. Soc., 79: 61-78.

U.S. ARMY COASTAL ENGINEERING CENTER - CERC. 1984. Shore protection manual. 41: pp. 603

ZHANG Y, PULLIAINEN JT, KOPONEN SS \& HALLIKAINEN MT. 2003. Water quality retrievals from combined Landsat TM data and ERS-2 data in the Gulf of Finland. IEEE Transactions on Geoscience and Remote Sensing, 41: 622-629. 